\title{
Climate and Weather of the North Pacific
}

\section{Kern E. Kenyon}

4632 North Lane, Del Mar, CA, USA

Correspondence to: Kern E. Kenyon, Kernken@aol.com

Keywords: Climate, Weather, North Pacific

Received: March 29, $2018 \quad$ Accepted: May 7, $2018 \quad$ Published: May 10, 2018

Copyright $\odot 2018$ by author and Scientific Research Publishing Inc.

This work is licensed under the Creative Commons Attribution International License (CC BY 4.0).

http://creativecommons.org/licenses/by/4.0/

\section{(c) (i) Open Access}

\section{ABSTRACT}

Combining two satellite cloud photographs of the eastern North Pacific separated by 18 hours in the spring of 1976 with concurrent weather measurements from the bridge of an oceanographic ship leads to the following propositions. Two clockwise curving long bands of clouds were each independently produced by cold air flowing south and pushing the warmer in situ air up and out of the way causing the clouds to form. The cloud bands are oriented roughly northeast/southwest with a separation of about 30 degrees of longitude at mid-latitudes. Curvature of the cloud bands is thought to be due to the Coriolis force acting on the southward flow. These conclusions could become more general if additional observations support them. A significant theoretical addition to an earlier discussion of the subject, regarding the time variability of approximately two days in the hypothesized circulation, is offered here along with a bit of confirming evidence from existing data. An old story with a new ending is presented.

\section{INTRODUCTION}

Here are the dictionary definitions from the OED.

Climate: The prevailing atmospheric phenomena and conditions of temperature, humidity, wind etc. (of a country or region).

Weather: The condition of the atmosphere at a given place and time with respect to heat, cold, sunshine, rain, cloud, wind, etc.

Much confusion surrounds the two terms, climate and weather, as used singly and also when they are attempted to be coupled together. For example, recent news reports are claiming that currently climate changes, particularly the ever so gradual global warming, can cause extremes of local weather more often than existed before. Then logic gets left behind even as believers accumulate.

Start afresh with what may seem like a radical departure (or omission) from the dictionary definitions: both climate and weather are intimately linked to the sun's influence and the earth's heat balance requirement. Weather is connected to the daily variation of the sun either at a given location or by flows advected into that location from a place usually to the west. Climate is related to the fact that the sun con- 
stantly pours down radiation, absorbed in the oceans mostly but also in the atmosphere, and the sun never goes away. Time-scales of weather are much shorter than those of climate by several hundred times; estimates are one to a few days on the average for weather during the stormy season and considerably more than one year for climate.

\section{CLIMATE}

Southern California's climate, where I grew up, is steady and mild. Usually one nice day follows another. Some people, who have lived elsewhere, call it boring. Weather events are few and far between: no wind or rain at all in the summer. Total average yearly rainfall near the coast is ten inches, making the region close to being a desert. Two months of morning fog, which burns off by noon, occur between spring and summer. Occasionally warm dry Santa Anna winds come out of the east.

This type of climate is no accident. Just offshore of San Diego sits the North Pacific High Pressure Cell, which is a permanent atmospheric feature that affects local weather events by steering storms away, off to the north. In summer the size of the zone of high sea level pressure markedly swells up to the west, or there could be two cells side by side longitudinally. In either case rains coming from the ocean are completely shut out of the San Diego area by this high pressure system during summers.

What makes the North Pacific High a permanent feature? Thirty years of monthly mean sea level pressures for the whole North Pacific show the High at nearly the same location off California for every month. The published pressure data in my possession consist of five degree latitude/longitude means arranged in a diamond grid starting in 1946.

It has been hypothesized that the high pressure feature is caused by heat leaking out of a wide warm surface current slowly heading northeast off California [1]. Based on thirty years of sea surface temperatures, compiled from millions of individual ship-injection temperatures (but still unpublished), the warm current is believed to be permanent also, and the North pacific High sits right on top of it most of the time.

Contrast the summer climate of southern California with the one in northwest Iowa, over 1500 miles from the North Pacific, where I have spent more than the last thirty summers in the same small town. There a calm day is rare. Significant wind occurs almost all the time: switching direction from the south, then from the north, and back again every couple of days all summer. North winds out of Canada are cold and dry, those from the south are warm and humid. When they collide around our town, rain occurs.

\section{WEATHER}

Commonly noticed at certain times at a given location, during falls through springs, in San Diego for example, is the fact that after a rain storm has come and gone, the air feels colder than it was before. Also as the storm is approaching the air warms up (and the wind comes out of the southwest). Maybe it is the cold air that has somehow led to the production of rain in the first place.

Starting an explanation of weather near San Diego is not difficult. At any given time of the year and any time of day or night over the open North Pacific the air near the sea surface is colder in the north and warmer in the south, all at the same level: sea level. That is an unstable arrangement because the denser cold air always has the tendency to rush southward pushing the less dense warm air up and out of the way in the process. Since this rushing of cold air southward is not observed to occur all the time, evidently some sort of trigger mechanism starts things going when conditions are right. During the day the sun warms up the air, and it does so more at low latitudes and less at high latitudes thereby creating an enhanced north/south temperature gradient and increasing the potential for an instability to take place, possibly around noon. That is one potential trigger method.

In a more technical particular example, Figure 1 and Figure 2 are two satellite photos from 1976 of the entire eastern North Pacific taken 18 hours apart, the first on March 29 (about 5:00 pm) and the second on March 30 (about 11:00 am). At that time I was on an oceanographic ship headed straight west along $35 \mathrm{~N}$ sailing from San Diego to Japan. At the time of the second photo the ship was at longitude 135 $\mathrm{W}$ at 12:00 am right in the middle of the extensive curved cloud band. The weather observations taken on 


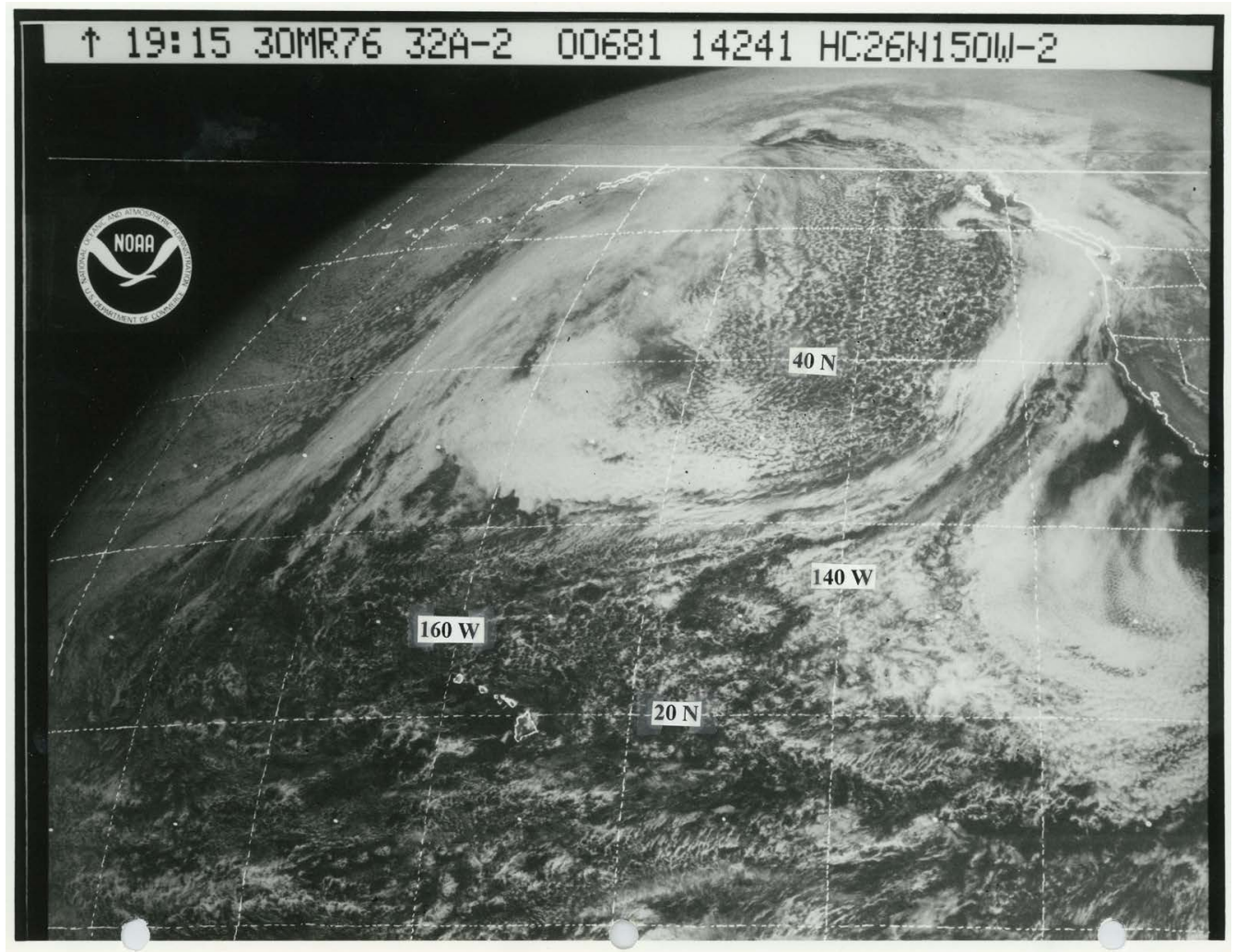

Figure 1. NOAA satellite image of the eastern North Pacific taken at 01:15 GMT on March 30, 1976.

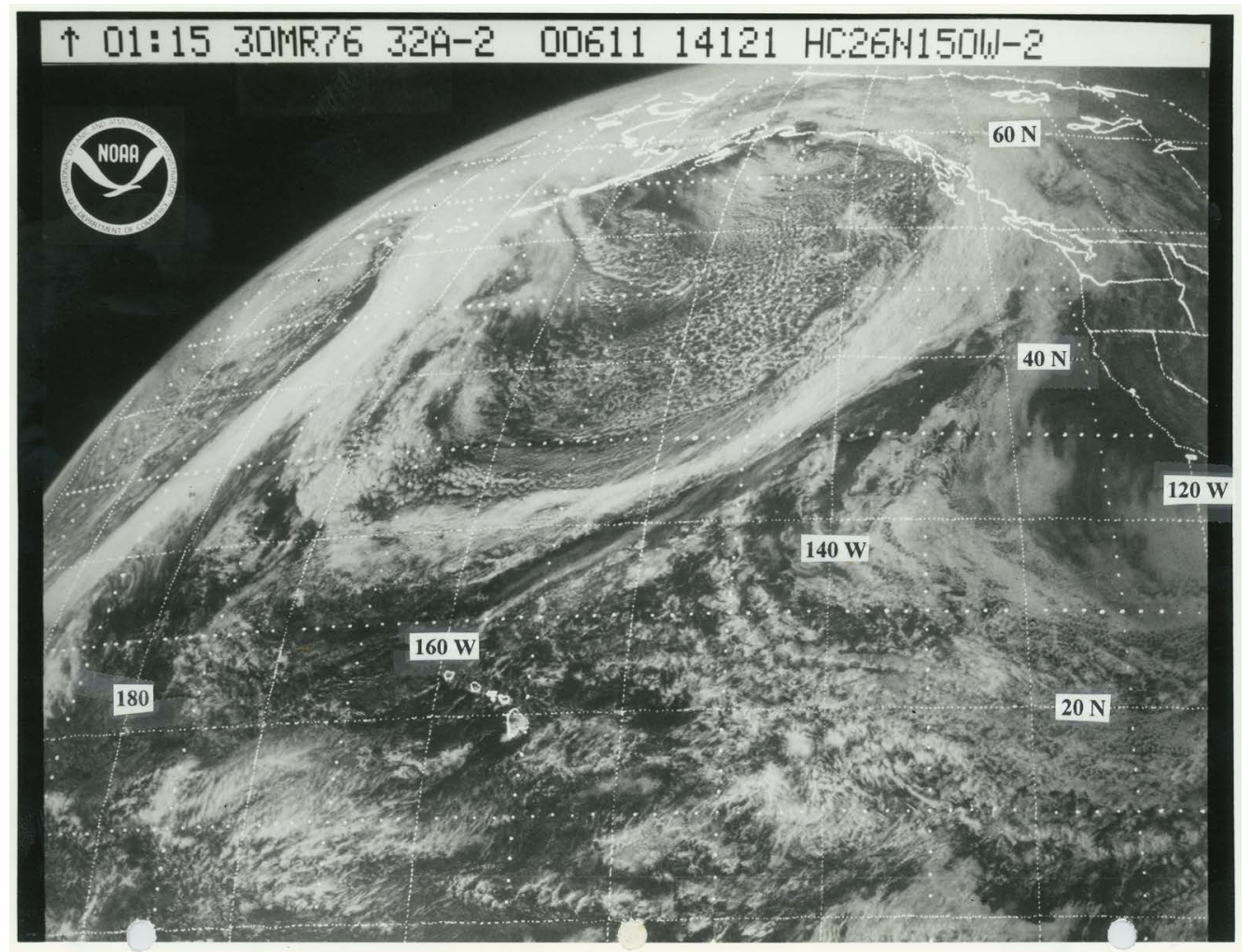

Figure 2. Similar to Figure 1 but taken at 19:15 on the same day. 
the bridge of the ship every two hours are in my possession. Every weather feature measured and recorded changed dramatically starting at 8:00 am on March 30 compared to the day before: the wind turned around to blow out of the north with speeds up to 30 knots!, the air temperature steadily dropped 8 degrees $\mathrm{F}$, pressure increased throughout the day, and the sea became rough with swell heights of $15 \mathrm{ft}$.

After the first rain storm hit the ship on March 30, the ship continued west and the second cloud band in Figure 1 and Figure 2 moved east to meet it. From the weather log data the meeting took place late on April 1, a little over two days later, when the wind came out of the north with increased speed and the air cooled down but not with the same intensity as displayed by the first cloud band. Maximum wind speeds were $2 / 3$ of what they were in the first storm. There are no satellite photos to go with these weather data, but they probably would not have been helpful due to the lateness of the hour.

\section{DISCUSSION}

Much information is contained in Figure 1 and Figure 2, and the ground truth greatly facilitates the interpretation of what they show. Although these figures have been published previously [2], there are some aspects of the earlier discussion that can be enhanced and adjusted to some extent. Justification for reopening the study and adding a bit of new thinking appears to be appropriate. A loosening up of the rigidity of the earlier model, or a modification the completely circular symmetry of the flow's plan form with a constant diameter, may better characterize what is coming next.

First, the eastern limbs of the cloud bands are long and coherent structures, and they always curve in the same way: clockwise as viewed from above. Many satellite photos since those in Figure 1 and Figure 2 have confirmed that. From a few ship-based measurements the air flow at sea level is apparently parallel to the inner edge of the cloud bands moving southwest, suggesting that it is the Coriolis force that is doing the bending. Second, the existence of the relatively thin cloud band marks the boundary between colder dryer air moving south into an environment of warmer humid air and pushing it up out of the way to make clouds. At least that assumption is adopted here as being reasonable. Third, the cloud band, which formed over the ocean, drifts eastward as a coherent feature at least until it strikes the US west coast. Such a fact evidently indicates that the formation mechanism of southward moving cold air is continuously working right up until bumping into the continent and perhaps somewhat beyond that.

What the ship's weather measurements confirm is the eastern half of the circulation pattern outlined by the cloud bands: the air flows south initially and gradually turns westward. But exactly how the horizontal circulation is closed is not explained by extrapolating from these data and not by earlier discussions either, nor by the observed cloud bands because they start looking not so well defined in the western part of the loop. More work needs to be done in this area. Also how soon can the next circulation to the west form behind the first one? What are the necessary conditions?

In Figure 1 the first cloud loop (farthest east) appears to bottom out and start heading back north in the western part of it just as the cloud band of the following loop (the eastern part of it) is heading south. In fact the two cloud bands join together. Surely some slowing down of both northward and southward motions associated with these two clouds bands must take place there. Consistent with this notion is the fact that the southward wind speeds of the western cloud band were significantly lower, when the ship intersected them, than were the southward speeds in the eastern cloud band the ship already encountered. Also consistent is the lack of any significant northward air stream, according to the ship's weather measurements, between the eastern cloud band and the coast that could slow down the southward flow associated with that cloud band, which was observed to be very fast (up to 30 knots).

Then a potentially counterintuitive proposal comes to mind, which is believed to be new in the present context. Taking it for granted that the Coriolis force bends the flows and thereby causes curves in the cloud bands, a slower flow speed should cause less curvature. As a direct consequence of that idea, deeper penetration of the colder air into lower latitudes should take place when the flow is slower. Figure 2 suggests that actually happened because the westernmost cloud band appears to head toward lower latitudes than where the eastern cloud band, with its higher speeds, bottomed out. However, this is only one 
sample and it takes place at the edge of the photograph. More data are needed. But this approach places perhaps a little less burden on the sun around local noon to keep up the approximately two day variability in the strength of neighboring circulation loops [3].

If the slowing and speeding up of the southward rushing cold air flows alternated back and forth over several to many days, that could help explain, in a somewhat different way than previously considered, the approximate two-day oscillation in all the weather variables that came out of filtering analyses applied to the complete meteorological records of the oceanographic cruise of 35 days [4].

Finally, the whole concept behind this study is that the atmosphere is partially adjusting its heat balance by having colder air go south and warmer air return north. Then one wonders about the relative efficiency of the mainly two arrangements: slower flows of cold air going further south than faster bursts of cold air bottoming out at a higher latitudes. Which one is more effective?

\section{CONCLUSIONS}

In the spring of 1976 two rain storms that formed over the North Pacific were captured by two satellite photos taken 18 hours apart. They had the following characteristics: long relatively thin cloud bands curved clockwise, directed south at high latitudes and bending evermore westward as the latitude decreased. Inside the eastern cloud band at $35 \mathrm{~N}$ an oceanographic ship measured several weather variables every two hours including wind speeds up to 30 knots directed south, air temperatures decreasing, and barometric pressure increasing. Also rough seas and swells 15 feet high were detected. A logical deduction is that during this storm cold dry air rushed south pushing the warmer humid environmental air up and out of the way causing clouds. Also it is proposed that the direction of the winds was constantly changed by the Coriolis force resulting in the curvature of the cloud band. A second western cloud band in the photos was encountered by the ship a couple of days later and the weather measurements showed similar characteristics though somewhat less intensive with smaller maximum southward wind speeds. New is the prediction that slower southward flows of cold air should penetrate to lower latitudes than faster flows due to the weaker curving caused by the smaller Coriolis force.

It is reasonable to suppose that these results exhibit a more general phenomenon than just the two storms in one particular year. Verification in the future is awaited when more observations become available.

\section{REFERENCES}

1. Kenyon, K.E. (1999) North Pacific High: An Hypothesis. Atmospheric Research, 51, 15-34. https://doi.org/10.1016/S0169-8095(98)00110-0

2. Kenyon, K.E. (1981) A Shallow Northeastward Current in the North Pacific. Journal of Geophysical Research, 86, 6529-6536. https://doi.org/10.1029/JC086iC07p06529

3. Kenyon, K.E. (1997) Inertial Air Flows over the North Pacific at Mid-Latitudes in Spring. Atmospheric Research, 43, 167-182. https://doi.org/10.1016/S0169-8095(96)00029-4

4. Kenyon, K.E. (1996) Bi-Daily Variation of Meteorological Properties at Sea Level in the Pacific along 35 N. Atmospheric Research, 43, 31-46. https://doi.org/10.1016/S0169-8095(96)00003-8 